University of Nebraska - Lincoln

DigitalCommons@University of Nebraska - Lincoln

USDA Wildlife Services - Staff Publications

U.S. Department of Agriculture: Animal and Plant Health Inspection Service

2010

\title{
Host-Specificity of Myxoma Virus: Pathogenesis of South American and North American Strains of Myxoma Virus in Two North American Lagomorph Species
}

\author{
L. Silvers \\ Australian National University, Canberra \\ D. Barnard \\ Utah State University, Logan, Institute for Antiviral Research \\ F. Knowlton \\ Utah State University, Logan, Institute for Antiviral Research \\ B. Inglis \\ Australian National University, Canberra
}

A. Labudovic

Australian National University, Canberra

See next page for additional authors

Follow this and additional works at: https://digitalcommons.unl.edu/icwdm_usdanwrc

Part of the Environmental Sciences Commons

Silvers, L.; Barnard, D.; Knowlton, F.; Inglis, B.; Labudovic, A.; Holland, M.K.; Janssens, P.A.; van Leeuwen, B.H.; and Kerr, P.J., "Host-Specificity of Myxoma Virus: Pathogenesis of South American and North American Strains of Myxoma Virus in Two North American Lagomorph Species" (2010). USDA Wildlife Services - Staff Publications. 965.

https://digitalcommons.unl.edu/icwdm_usdanwrc/965

This Article is brought to you for free and open access by the U.S. Department of Agriculture: Animal and Plant Health Inspection Service at DigitalCommons@University of Nebraska - Lincoln. It has been accepted for inclusion in USDA Wildlife Services - Staff Publications by an authorized administrator of DigitalCommons@University of Nebraska - Lincoln. 


\section{Authors}

L. Silvers, D. Barnard, F. Knowlton, B. Inglis, A. Labudovic, M.K. Holland, P.A. Janssens, B.H. van Leeuwen, and P.J. Kerr

This article is available at DigitalCommons@University of Nebraska - Lincoln: https://digitalcommons.unl.edu/ icwdm_usdanwrc/965 


\title{
Host-specificity of myxoma virus: Pathogenesis of South American and North American strains of myxoma virus in two North American lagomorph species
}

\author{
L. Silvers ${ }^{\text {a,b }}$, D. Barnard ${ }^{\text {b }}$, F. Knowlton ${ }^{\text {c }}$, B. Inglis ${ }^{a}$, A. Labudovic ${ }^{a}$, M.K. Holland ${ }^{\text {d }}$, P.A. Janssens ${ }^{\text {a }}$, \\ B.H. van Leeuwen ${ }^{a}$, P.J. Kerr ${ }^{\mathrm{e}, *}$ \\ ${ }^{\text {a } S c h o o l ~ o f ~ B i o c h e m i s t r y ~ a n d ~ M o l e c u l a r ~ B i o l o g y, ~ C o l l e g e ~ o f ~ S c i e n c e, ~ A u s t r a l i a n ~ N a t i o n a l ~ U n i v e r s i t y, ~ C a n b e r r a, ~ A C T, ~ A u s t r a l i a ~}$ \\ ${ }^{\mathrm{b}}$ Institute for Antiviral Research, Utah State University, Logan, UT, USA \\ ${ }^{\mathrm{c}}$ National Wildlife Research Center, Utah State University, Logan, UT, USA \\ ${ }^{\mathrm{d}}$ School of Veterinary Science, University of Queensland, Gatton, Queensland, Australia \\ e CSIRO Entomology, Clunies-Ross Street, GPO Box 1700, Canberra, Acton, ACT 2601, Australia
}

\section{A R T I C L E I N F O}

\section{Article history:}

Received 8 July 2009

Received in revised form 17 September 2009 Accepted 22 September 2009

\section{Keywords:}

Myxomatosis

Myxoma virus

Sylvilagus

Pathogenesis

Rabbit

\begin{abstract}
A B S T R A C T
The pathogenesis of South American and North American myxoma viruses was examined in two species of North American lagomorphs, Sylvilagus nuttallii (mountain cottontail) and Sylvilagus audubonii (desert cottontail) both of which have been shown to have the potential to transmit the South American type of myxoma virus. Following infection with the South American strain (Lausanne, Lu), S. nuttallii developed both a local lesion and secondary lesions on the skin. They did not develop the classical myxomatosis seen in European rabbits (Oryctolagus cuniculus). The infection at the inoculation site did not resolve during the 20-day time course of the trial and contained transmissible virus titres at all times. In contrast, S. audubonii infected with Lu had very few signs of disseminated infection and partially controlled virus replication at the inoculation site. The prototype Californian strain of myxoma virus (MSW) was able to replicate at the inoculation site of both species but did not induce clinical signs of a disseminated infection. In S. audubonii, there was a rapid response to MSW characterised by a massive T lymphocyte infiltration of the inoculation site by day 5. MSW did not reach transmissible titres at the inoculation site in either species. This might explain why the Californian myxoma virus has not expanded its host-range in North America.
\end{abstract}

Crown Copyright @ 2009 Published by Elsevier B.V. All rights reserved.

\section{Introduction}

Changes in species distribution that are occurring due to alterations in land use, habitat fragmentation, and climate change are exposing humans, domestic animals and wildlife to novel pathogens (Lebarbenchon et al., 2008; Patz et al., 2004). The mechanisms by which viruses are able to shift between host species to cause novel diseases or are constrained by species barriers to a single species are

\footnotetext{
* Corresponding author.

E-mail address: peter.kerr@csiro.au (P.J. Kerr).
}

of major importance in infectious disease research (McFadden, 2005). Natural models of species jumps and emerging disease are thus of great interest for understanding the barriers to pathogens shifting hosts or the factors that enable pathogens to emerge.

One of the classic examples of an emerging disease is that of the introduction of myxoma virus into the European rabbit (Oryctolagus cuniculus) population of Australia and Europe and its subsequent coevolution with this novel host species (Fenner and Fantini, 1999). Myxoma virus is a poxvirus in the genus Leporipoxvirus. There are two major geographic types of myxoma virus: the South American (Brazilian) for which the natural host is Sylvilagus 
brasiliensis, the tapeti or jungle rabbit, and the North American (Californian) for which the natural host is Sylvilagus bachmani, the brush rabbit. In its natural host, each type of myxoma virus causes a discrete cutaneous fibroma at the inoculation site from which virus can be transmitted on the mouthparts of biting arthropods such as mosquitoes or fleas. The virus does not replicate in the vector. Neither virus appears to cause disseminated disease in immunocompetent natural hosts, but the South American type has been recorded as causing disseminated disease in very young $S$. brasiliensis (Fenner and Ratcliffe, 1965). Each virus type is highly adapted to its natural host and does not transmit from the other host (Marshall and Regnery, 1963; Regnery and Marshall, 1971). However, in the European rabbit (O. cuniculus) both types of myxoma virus cause the lethal disseminated disease myxomatosis. A third leporipoxvirus, Shope fibroma virus, is present in Sylvilagus floridanus (eastern cottontail) in North America. Although genetically and antigenically closely related to myxoma virus, this virus does not cause disseminated disease in immunocompetent European rabbits (Cameron et al., 1999; Fenner, 1965; Woodroofe and Fenner, 1965; Willer et al., 1999) but induces a cutaneous fibroma at the inoculation site.

Myxoma virus has a double strand DNA genome of $161 \mathrm{~kb}$. Like other poxviruses, the central part of the genome contains genes required for virus replication and assembly that tend to be conserved across the poxvirus family. However, the outer parts of the genome encode genes required for host-specificity and immune modulation that tend to be unique to the leporipoxviruses (Cameron et al., 1999; Willer et al., 1999; Stanford et al., 2007). These genes are presumed to have closely evolved with the natural host in order to allow the virus to replicate and maintain high titres in the epidermis at the inoculation site for sufficient time to be transmitted by biting arthropods. In the European rabbit, these factors overwhelm the host immune response leading to disseminated lethal disease (Kerr and McFadden, 2002).

Myxoma virus has a narrow host-range limited to a small group of leporids (Fenner and Ratcliffe, 1965), two species of North American leporids, Sylvilagus nuttallii (mountain cottontail) and Sylvilagus audubonii (desert cottontail) are susceptible to infection with South American strains of myxoma virus and could potentially transmit the virus (Regnery, 1971). S. nuttallii exists in the western USA from Dakota to central New Mexico while S. audubonii has a broader distribution through the southwestern USA and Mexico (Fox, 1994). S. audubonii overlaps with $S$. bachmani through part of its range and is exposed to myxoma virus (Marshall et al., 1963) whereas S. nuttallii has no known exposure to myxoma virus. Experimentally, neither species was able to transmit a Californian strain of myxoma virus via mosquito feeding (Regnery and Marshall, 1971).

As part of developing and extending understanding of the species-specificity of myxoma viruses and the diseases they cause, this paper describes the pathogenesis of a South American prototype strain Brazil/Campinas 1949 also known as the Lausanne strain (Lu) and the North American prototype strain San Francisco 1950/1 (MSW)
(Fenner and Marshall, 1957), in both S. nuttallii and S. audubonii. Both of these viruses are of grade 1 virulence for European rabbits, i.e., $100 \%$ mortality with an average survival time of $\leq 13$ days following intradermal inoculation (Fenner and Marshall, 1957).

\section{Methods}

\subsection{Viruses and tissue culture}

The Lausanne (Lu) strain of myxoma virus (Brazil/ Campinas/1949) was derived from an ampoule of freezedried virus produced by the Commonwealth Serum Laboratories, Melbourne, Australia (batch 048-1; 3 July 1973) as a grade 1 virulence virus for biological control of European rabbits. This virus was passaged once in a laboratory rabbit and stocks prepared as a testis homogenate. The MSW strain of myxoma virus (San Francisco 1950/1) was prepared by a single rabbit passage from a freeze-dried tissue extract dated February 1956 obtained from Prof. Frank Fenner, John Curtin School of Medical Research, Canberra, Australia. Grade 1 virulence of the virus for European rabbits was confirmed in laboratory rabbits (Silvers et al., 2006).

Vero and RK13 cells were maintained in minimal essential medium (MEM) supplemented with 10\% foetal calf serum at $37{ }^{\circ} \mathrm{C}$ in an atmosphere of $5 \% \mathrm{CO}_{2} / 95 \%$ air.

\subsection{Breeding and maintenance of S. nuttallii and S. audubonii}

S. audubonii breeding stock was trapped at Pinion Canyon, Colorado. S. nuttallii was captured in Cache and Box Elder counties, Utah. Kittens bred from these stock were reared in communal outdoor pens. For experimental use, animals were moved to the Laboratory Animal Research Centre at Utah State University. Here animals were housed under containment level 2 conditions in individual cages with cardboard boxes for shelter. Temperature was held at $22^{\circ} \mathrm{C}$, and a $12 \mathrm{~h}$ light/dark cycle was imposed. Standard pelleted rabbit food and water were available ad libitum supplemented with fresh carrots daily. Prior to entering the facility, animals were treated for internal and external parasites. During a 7-day acclimation period, animals were monitored to ensure that water and food dispensers were being used and rectal temperatures were taken daily. All animals were housed and maintained according to the recommendations of IACUC, Utah State University, Logan, Utah, permit \#913.

\subsection{Experimental protocol}

For each pathogenesis experiment 12 S. nuttallii and 12 S. audubonii cottontails over 3 months old were used. Prior to infection the animals were weighed, rectal temperatures taken and a $1 \mathrm{ml}$ blood sample was collected from the marginal ear vein. Each rabbit was then injected with either $1000 \mathrm{pfu}$ of Lu or $1000 \mathrm{pfu}$ of MSW in a volume of $100 \mu \mathrm{l}$ of PBS ( $\mathrm{pH} 7.2$ ) intradermally at a single site of the shaved skin of the dorsal surface of the hind foot. $S$. audubonii was inoculated in the left hind foot and $S$. nuttallii in the right hind foot. Gender was not used as a 
variable in the study design as the animals used reflected what was available from the breeding colony at the appropriate time and age. The genders used for Lu were $S$. audubonii 10 female, 2 male; S. nuttallii 12 male. For MSW six female and six male rabbits were used for each species. Rabbits were examined and clinical signs and rectal temperatures recorded each day. Animals were weighed and blood samples were collected at 5-day intervals. In each group, three rabbits were euthanized, with an overdose of intravenous pentobarbitone, at 5, 10, 15 and 20 days after infection. The rabbits were autopsied and tissues were collected from the inoculation site on the hind foot, eyelid and the skin of the uninoculated hind foot (distal skin), the popliteal lymph node draining the inoculation site (draining lymph node) and the popliteal lymph node from the opposite hind leg (contralateral lymph node), spleen, left kidney, liver, thymus, testis and left lung. Tissues were divided for histopathological processing $\left(10 \%\right.$ formalin) or frozen $\left(-70^{\circ} \mathrm{C}\right)$ for virus extraction and titration as described previously (Best et al., 2000; Best and Kerr, 2000; Silvers et al., 2006).

\subsection{Virus titration}

Virus titres in tissues from rabbits infected with Lu were determined by plaque assay on Vero cell monolayers (Best and Kerr, 2000). MSW forms very poor plaques which are difficult to count reliably therefore titres were determined as tissue culture infectious dose $50 \%$ endpoints ( $\mathrm{TCID}_{50}$ ) on RK13 cell monolayers in 96-well flat-bottomed plates as previously described (Silvers et al., 2006). Limits of detection were $100 \mathrm{pfu} / \mathrm{TCID}_{50} / \mathrm{g}$.

\subsection{Antibody measurements}

Serum antibody to myxoma virus was measured by ELISA, using Lu as antigen, as previously described (Kerr, 1997). Gel immunoprecipitation tests confirmed that sera from Sylvilagus species reacted with the anti-rabbit immunoglobulin used for detection in ELISA (data not shown).

\subsection{Histology}

Formalin fixed tissues were trimmed, embedded in paraffin wax, sectioned at $4 \mu \mathrm{m}$, stained with haematoxylin and eosin and examined by light microscopy. Immunohistochemistry used an antigen retrieval protocol and immunoperoxidase staining as previously described (Silvers et al., 2006). Myxoma virus antigen was detected with monoclonal antibody 3B6E4 (Fountain et al., 1997). Rabbit $\mathrm{T}$ lymphocytes were detected with mouse-antirabbit CD43 monoclonal antibody (clone L11/135; Wilkinson et al., 1992; Serotec).

\section{Results}

3.1. Clinical signs of infection of S. nuttallii and

S. audubonii with $\mathrm{Lu}$

Mean rectal temperatures prior to infection for both species fell within the range of $38.8-39.4^{\circ} \mathrm{C}$. Following infection, rectal temperatures increased from day 4 and mean rectal temperatures stayed above $40^{\circ} \mathrm{C}$ for the duration of the experiment for S. audubonii. For S. nuttallii, mean rectal temperatures were below $40^{\circ} \mathrm{C}$ between days 10 and 15 but returned to above $40^{\circ} \mathrm{C}$ from day 15 (Fig. 1A). The mean body weights of $S$. audubonii trended downwards from day 10 while $S$. nuttallii tended to increase in body weight over the course of the trial (Fig. 1B).

A primary lesion of thickened and swollen epidermis at the inoculation site was first visible at day 4 in S. nuttallii. By day 8, slight ano-genital swelling was present in two rabbits and one of these rabbits had slightly red eyelid margins. All of the animals had slightly swollen red eyelids by day 10 and secondary cutaneous lesions were present at the base of the ears, on the nose and eyelids and limbs in some animals. Between days 10 and 15 the primary lesions became extremely swollen and red and began to engulf the dorsum of the foot. Secondary lesions increased in size to about $2 \mathrm{~cm}$ in diameter. The ears became extremely swollen by day 13 and some rabbits had secondary lesions on the eyelids while ano-genital swelling was prominent in some animals. Primary lesions continued to increase in size and by day 20 were protuberant, glossy, depilated and dark purple. The ears of all animals were swollen, particularly at the base and the ano-genital areas were severely swollen. Although the demeanour of the rabbits had become
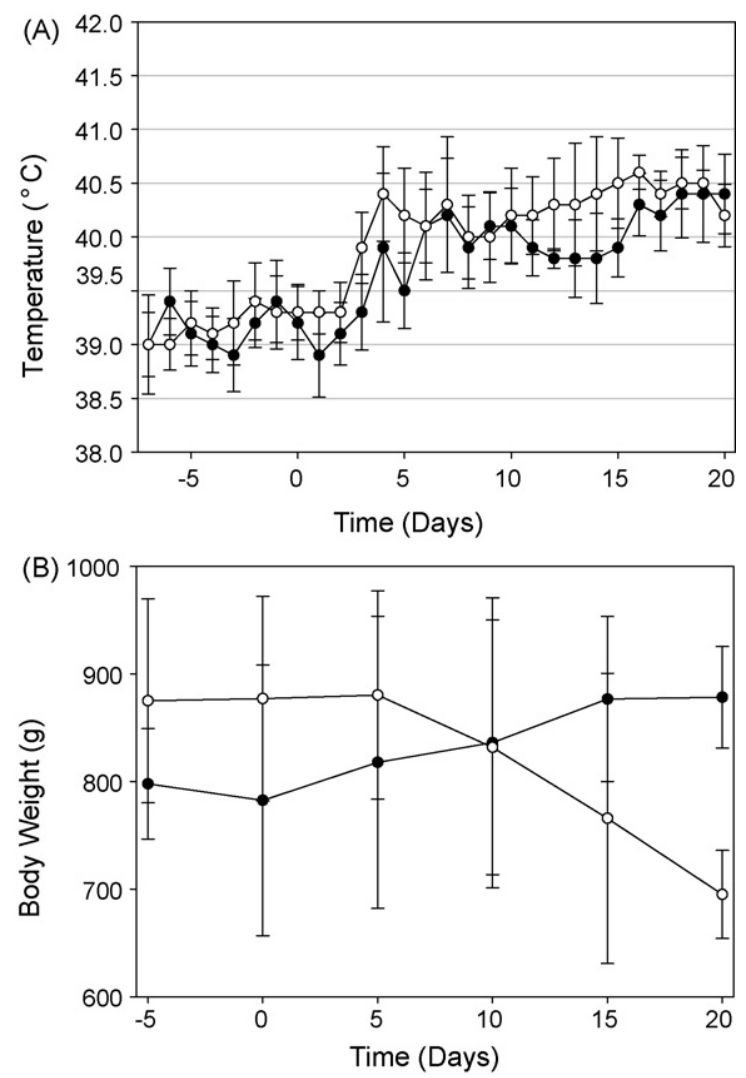

Fig. 1. Rectal temperatures (A) and body weights (B) of S. audubonii (open circles) and S. nuttallii (shaded circles) infected with Lu. Error bars show standard error. 

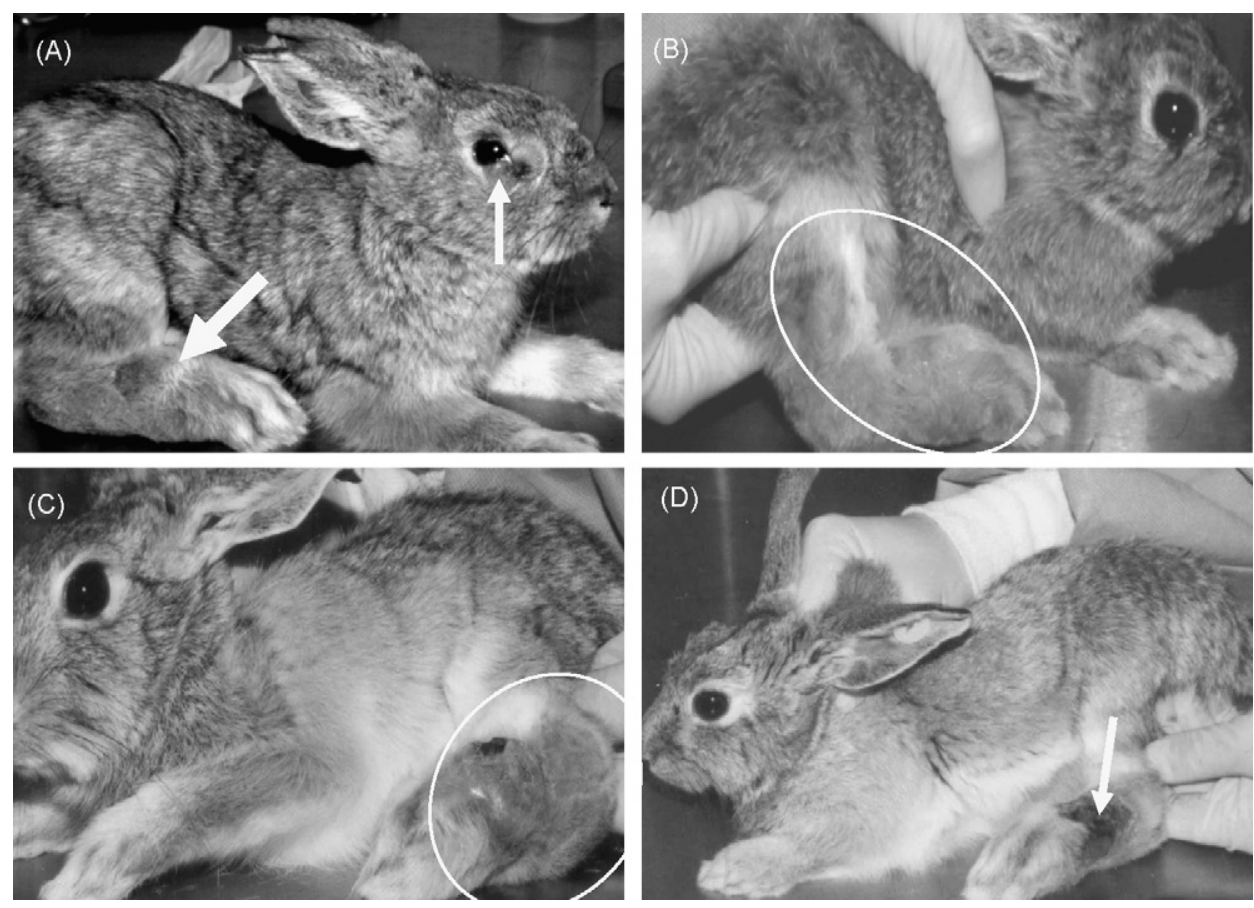

Fig. 2. Clinical signs at day 20 of $S$. nuttallii and S. audubonii infected with Lu. (A) S. nuttallii: large arrow indicates grossly swollen hind leg and inoculation site; small arrow indicates secondary lesion on face. (B) S. nuttallii showing grossly swollen hind leg. (C) S. audubonii with heavily scabbed and swollen inoculation site (circled). (D) S. audubonii: arrow indicates heavily scabbed inoculation site.

slightly depressed, all rabbits were eating and drinking normally as judged both by observation and by bladder, stomach and intestinal contents at autopsy. Fig. 2A shows the swollen hind leg and a secondary lesion on the face of a S. nuttallii infected with Lu at day 20. Fig. 2B shows the very swollen hind leg in a separate animal.

The primary lesions developed more rapidly in $S$. audubonii infected with Lu, compared to S. nuttallii, and by day 4 covered $30-40 \%$ of the dorsum of the foot. By day 7 , several rabbits had slightly swollen eyelids and two had slight ano-genital swelling. By day 10 the primary lesion covered most of the dorsum of the foot, it was hairless, glossy and beginning to weep. After this time, the lesions became quite raw with bright red gelatinous portions around the outer surface and began to scab. Eyelids returned to normal but two rabbits still had severe ano-

Table 1

Pathology in Sylvilagus nuttallii and Sylvilagus audubonii infected with Lu.

\begin{tabular}{|c|c|c|}
\hline Day & Sylvilagus nuttallii & Sylvilagus audubonii \\
\hline 5 & $\begin{array}{l}\text { Primary lesions slightly thickened, gelatinous and partially } \\
\text { haemorrhagic when viewed from below. Draining lymph } \\
\text { nodes were approximately four times normal size and dark } \\
\text { crimson to black. Spleens and contralateral lymph nodes } \\
\text { appeared normal. }\end{array}$ & $\begin{array}{l}\text { Primary lesions } 0.7 \mathrm{~cm} \text { thick with a layer of translucent gelatinous } \\
\text { material below slightly haemorrhagic layers of epidermis and } \\
\text { dermis. Draining lymph nodes were approximately } 50 \% \text { larger } \\
\text { than normal with purple crimson patches. Spleens and } \\
\text { contralateral lymph nodes appeared normal. }\end{array}$ \\
\hline 10 & $\begin{array}{l}\text { Primary lesions extremely gelatinous; exuded straw coloured } \\
\text { fluid. Dermal and epidermal layers were swollen and red. } \\
\text { Draining lymph nodes were } 8-10 \text { times normal size with a } \\
\text { mottled haemorrhagic appearance. Contralateral lymph nodes } \\
\text { were slightly enlarged. Spleens appeared normal. }\end{array}$ & $\begin{array}{l}\text { Primary lesions extremely swollen, red and gelatinous. Straw } \\
\text { coloured fluid oozing from cut sections. Draining lymph nodes } \\
\text { were about six times normal size with purple blotches on the } \\
\text { surface and cut surface. Spleens and contralateral lymph } \\
\text { nodes appeared normal. }\end{array}$ \\
\hline 15 & $\begin{array}{l}\text { Primary lesions approximately } 2 \mathrm{~cm} \text { thick and grossly haemorrhagic. } \\
\text { The epidermis and dermis were red and covered a } 1 \mathrm{~cm} \text { layer of } \\
\text { pale yellow gelatinous material. Draining lymph nodes were } \\
\text { approximately } 12 \text { times normal size. Contralateral lymph } \\
\text { nodes were moderately enlarged and haemorrhagic. } \\
\text { Spleens appeared normal. }\end{array}$ & $\begin{array}{l}\text { Primary lesions extremely swollen; dermal and epidermal } \\
\text { layers indistinguishable. Gelatinous layer now bright red and } \\
\text { dotted with purple/black spots of coagulated blood. Draining } \\
\text { lymph nodes were approximately six times normal size, } \\
\text { haemorrhagic on the outside but not on the cut surface. } \\
\text { Spleens and contralateral lymph nodes appeared normal. }\end{array}$ \\
\hline 20 & $\begin{array}{l}\text { Primary lesions were } 1.5 \mathrm{~cm} \text { thick and similar in appearance to } \\
\text { day } 15 \text {. Draining lymph nodes were grossly enlarged; } \\
\text { contralateral lymph nodes were moderately enlarged and } \\
\text { haemorrhagic. Spleens appeared normal. Secondary lesions } \\
\text { had similar properties to the primary lesion. }\end{array}$ & $\begin{array}{l}\text { Primary lesions consisted of a hard black scab overlying red, } \\
\text { semi-translucent gelatinous material grading down to firm } \\
\text { white tissue in the deeper zones. A small volume of serous } \\
\text { material seeped from the cut sections. Secondary lesions had } \\
\text { a similar appearance. Draining lymph nodes were similar } \\
\text { to day } 15 \text {. One contralateral node was enlarged. Spleens } \\
\text { appeared normal. }\end{array}$ \\
\hline
\end{tabular}



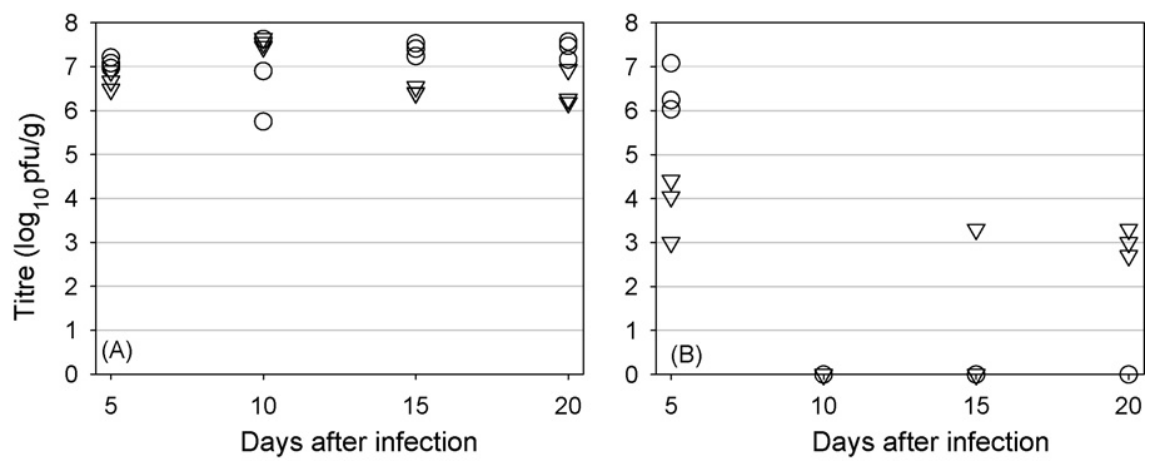

Fig. 3. Virus titres at inoculation site (A) and draining lymph nodes (B) of S. nuttallii (circles) and S. audubonii (inverted triangles) infected with Lu. Limits of detection $100 \mathrm{pfu} / \mathrm{g}$.

genital swelling. From day 16, large black scabs began to form across the primary lesions, this was associated with reluctance to use the leg and depressed demeanour. Fig. 2C and $\mathrm{D}$ shows the range of lesions at the inoculation site at day 20 in S. audubonii. Secondary lesions were uncommon; one secondary lesion was recorded on the left hind leg of one rabbit and a secondary lesion was also found in the genital region of another.

At no time did any of the animals of either species infected with Lu have the classical muco-purulent discharge from the conjunctivae and nasal passages, massive swelling and closure of the eyelids and obstruction of the nostrils that is typical for European rabbits infected with Lu or other virulent South American strains of myxoma virus.

\subsection{Autopsy findings in S. nuttallii and S. audubonii infected with $\mathrm{Lu}$}

For both S. nuttallii and S. audubonii, pathology was limited to the external primary and secondary lesions on the skin, swelling of the ears and ano-genital regions and the draining lymph nodes (Table 1 ). There were no abnormalities observed in other tissues at autopsy.

\subsection{Titres of Lu in tissues of S. nuttallii and S. audubonii infected with $\mathrm{Lu}$}

Titres of $\mathrm{Lu}$ in the skin at the inoculation site of $S$. nuttallii were above $10^{7} \mathrm{pfu} / \mathrm{g}$ at day 5 and remained around this titre for the duration of infection (Fig. 3A). Similar or slightly lower titres were present in the primary lesions of $S$. audubonii at days 5 and 10 but by day 15 the titres in this species had dropped below $10^{7} \mathrm{pfu} / \mathrm{g}$ (Fig. 3A). In European rabbits this titre is the threshold for mosquito transmission (Fenner et al., 1956).

At day 5 , there were titres of $10^{6}$ to $10^{7} \mathrm{pfu} / \mathrm{g}$ in the lymph node draining the primary lesions of $S$. nuttallii, however, virus was not present at subsequent timepoints. The titres of virus in the draining lymph nodes of S. audubonii were 10-1000-fold lower at day 5 than those of S. nuttallii; small amounts of virus were present at day 15 in one animal and day 20 in all three animals (Fig. 3B).
Low concentrations of Lu were detected in the contralateral popliteal lymph nodes of $S$. nuttallii at all time-points and Lu was also detectable in the lung (Fig. 4). Low levels of virus (100-1000 pfu/g) were present in the thymus of some animals at days 10 and 20 and a trace of virus ( $100 \mathrm{pfu} / \mathrm{g}$ ) was detected in the spleen of one animal at day 10 . No virus was detected in the testis at any time. Lu was not detected in the contralateral lymph nodes, spleen, lungs, liver, testes, or kidneys of $S$. audubonii. However, 10 of the $12 \mathrm{~S}$. audubonii were female so testes were only available from one rabbit at day 10 and one at day 20.

Skin from the uninoculated hind foot (distal skin) was excised at autopsy and assayed for virus and similarly any secondary lesions were excised and assayed. Low titres of Lu $\left(10^{2.7}\right.$ to $\left.10^{4} \mathrm{pfu} / \mathrm{g}\right)$ were present in the distal skin of $S$. nuttallii at days 15 and 20. Two of three secondary lesions excised at day 20 contained more than $10^{7} \mathrm{pfu} / \mathrm{g}$ of virus. However, Lu was not detected in eyelids of S. nuttallii at any time point despite the clinical involvement of these tissues. No Lu was detected in the distal skin of $S$. audubonii. However, virus titres of 1000-3000 pfu/g were present in eyelids at day 10 only. A secondary lesion excised from the genital region at day 20 contained $10^{6.8} \mathrm{pfu} / \mathrm{g}$.

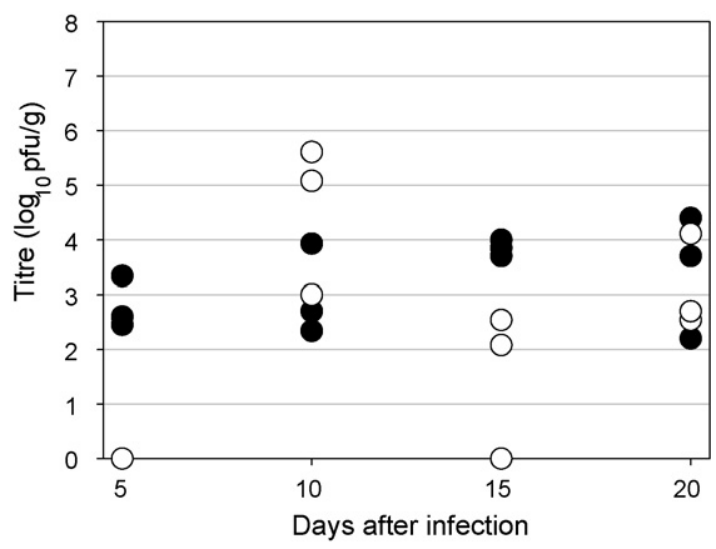

Fig. 4. Virus titres in distal lymph nodes (closed circles) and lung (open circles) of S. nuttallii infected with Lu. Limits of detection $100 \mathrm{pfu} / \mathrm{g}$. 

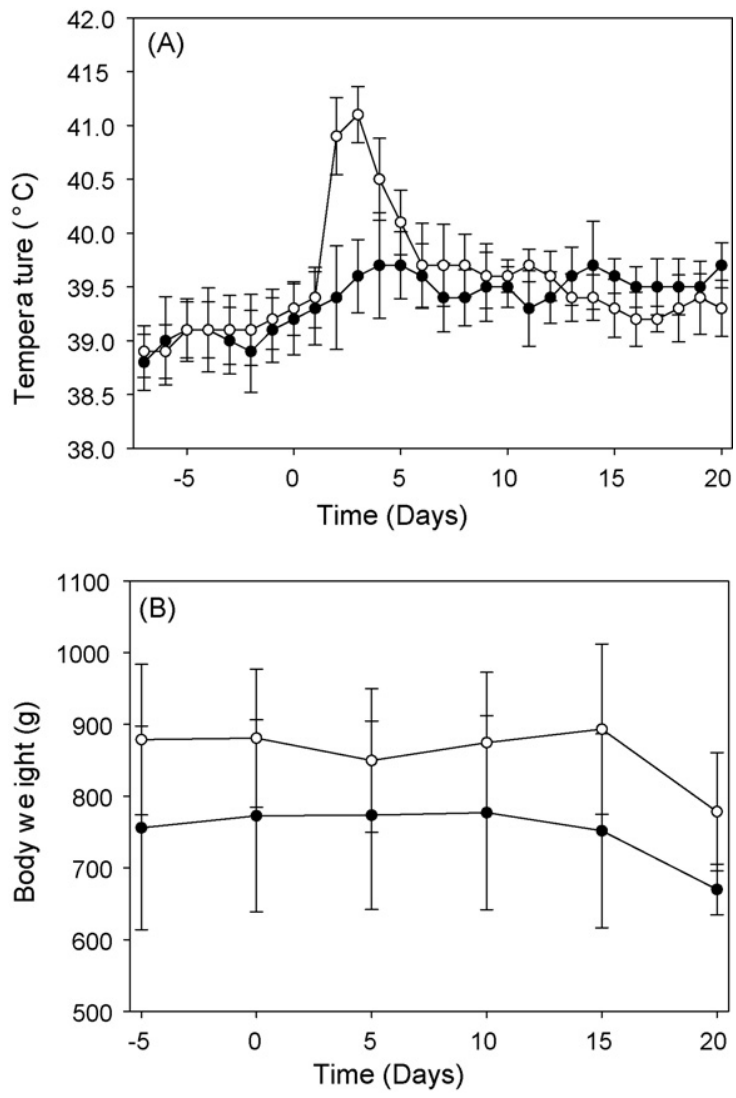

Fig. 5. Rectal temperatures (A) and body weights (B) of S. nuttallii (shaded circles) and $S$. audubonii (open circles) infected with MSW. Error bars show standard error.

\subsection{Antibody response to Lu infection in $\mathrm{S}$. nuttallii and S. audubonii}

Antibodies to myxoma virus were detected by ELISA at low titres (100-200) at day 10 and increased to 160025,600 by day 15 . At day 20 , antibody titres ranged from 6400 to 102,400 in $S$. audubonii and were 51,200 in $S$. nuttallii. At other time-points, the titres were similar in both species.

\subsection{Clinical signs of infection of S. nuttallii and S. audubonii with MSW}

In S. nuttallii, slight redness was present at the inoculation site of MSW at day 2 and by day 5 the skin at the inoculation site was slightly thickened. By day 9 the primary cutaneous lesion was approximately $1.5 \mathrm{~cm} \times 2 \mathrm{~cm}$ and $0.3 \mathrm{~cm}$ in height. Over the next 3 days the lesions changed colour from red to purple, became more rounded and began to harden; by day 15 scabs were forming over the lesion and by day 20 the primary lesions were either rubbery or had dried to a thick black scab. During this time period, mean rectal temperatures trended upwards compared to the preinfection period but remained below $40^{\circ} \mathrm{C}$ (Fig. 5A). There was also a slight downward trend in weight of the infected rabbits (Fig. 5B).
S. audubonii infected with MSW also had redness at the inoculation site at day 2 and by day 3 the majority of rabbits also had slightly reddened eyelids. These signs were associated with a strong febrile response with mean rectal temperature increasing to $41.1^{\circ} \mathrm{C}$ on day 3 (Fig. 5A). Rectal temperatures returned to the normal range over the next 3 days while the primary cutaneous lesion increased in size, becoming dark red and raised. By day 7, some scab formation was occurring. Lesions reached their largest size by day 9 when they were approximately $2 \mathrm{~cm} \times 3 \mathrm{~cm}$ wide and up to $1 \mathrm{~cm}$ in height. Lesions continued to resolve, developing thick scabs, over the remainder of the 20-day period. Similar to S. nuttallii infected with MSW, there was a trend to some weight loss over the last 5 days of the infection (Fig. 5B). No other clinical signs were observed. Secondary lesions or signs of classical myxomatosis were not a feature of infection with MSW in either species.

\subsection{Pathological findings at autopsy of S. nuttallii and S. audubonii infected with MSW}

The gross pathology of $S$. nuttallii and $S$. audubonii following infection with MSW was limited to the site of inoculation and enlarged lymph nodes and spleen. Autopsy findings are summarised in Table 2.

\subsection{Titres of MSW in tissues from S. nuttallii and S. audubonii}

MSW titres in S. nuttallii at the primary inoculation site remained between $10^{3}$ and $10^{6} \mathrm{TCID}_{50} / \mathrm{g}$ (Fig. 6A). Similar titres were present at the primary inoculation site of $S$. audubonii (Fig. 6A). Low titres of MSW were detected in the draining lymph nodes of $S$. nuttallii at days 10 and 15 and at all time-points in S. audubonii (Fig. 6B); these titres were at the threshold of detection. MSW was not found in contralateral nodes at any time point in either species. MSW was present in distal skin sites from $S$. nuttallii at all time-points at low titres $\left(10^{2}\right.$ to $10^{4} \mathrm{TCID}_{50} / \mathrm{g}$; Fig. $\left.6 \mathrm{C}\right)$ and similar titres were found in the eyelids at 5 and 15 days. Similarly, MSW was found at low titres in the distal skin and eyelids of $S$. audubonii. MSW was not detected in lung, thymus, spleen, testis, kidney or liver of either S. nuttallii or $S$. audubonii at any time-points.

3.8. Antibody response to infection with MSW in S. nuttallii and $S$. audubonii

Antibodies were not detected in serum from either species until day 15 and then at titres of 100-200. At day 20 titres for the three S. audubonii were 400, 400 and 800 and for $S$. nuttallii, 200, 6400 and $<50$. The low antibody titres may partially reflect antigenic differences between MSW and the Lu antigen used in the ELISA.

\subsection{Virus localization and histopathology of Lu infection}

Histopathological features in the skin at the inoculation site of Lu were similar in the Sylvilagus species to those reported in 0 . cuniculus infected with virulent myxoma virus (Best et al., 2000; Hurst, 1937a; Rivers, 1930). The key features were the proliferation of epidermal cells with 
Table 2

Pathology of Sylvilagus nuttallii and Sylvilagus audubonii infected with MSW

\begin{tabular}{|c|c|c|}
\hline Day & Sylvilagus nuttallii & Sylvilagus audubonii \\
\hline 5 & $\begin{array}{l}\text { Skin at inoculation site slightly thickened and gelatinous. Draining lymph } \\
\text { nodes were five times normal size, haemorrhagic, purple and turgid. } \\
\text { Contralateral nodes were twice normal size with blotchy haemorrhages } \\
\text { on the surface. Spleens were normal. }\end{array}$ & $\begin{array}{l}\text { Skin at inoculation site was thickened with a gelatinous } \\
\text { layer beneath the epidermis which exuded serum. } \\
\text { Draining lymph nodes were approximately } 10 \text { times normal } \\
\text { size and very haemorrhagic. Contralateral nodes were } \\
\text { slightly enlarged with small amounts of haemorrhage } \\
\text { on the cut surface. Spleens were swollen and about } \\
25 \% \text { larger than normal. }\end{array}$ \\
\hline 10 & $\begin{array}{l}\text { Primary lesions were swollen and bloody beneath the skin. The lesion } \\
\text { consisted of a clear gelatinous mass which exuded serum on excision. } \\
\text { Lymph nodes were enlarged as at day } 5 \text { but contralateral nodes } \\
\text { did not show any signs of haemorrhage. Spleens were normal. }\end{array}$ & $\begin{array}{l}\text { At day } 10 \text { the gelatinous layer in the primary lesion had } \\
\text { been replaced by a white fibroma like mass. Draining } \\
\text { lymph nodes and spleens were still enlarged but } \\
\text { appeared normal on sectioning. }\end{array}$ \\
\hline 15 & $\begin{array}{l}\text { Lesions were about } 0.5 \mathrm{~cm} \text { thick, dark red and gelatinous. Draining lymph } \\
\text { nodes were around eight times normal size and pale red in colour. } \\
\text { Contralateral nodes were normal size but two of three were dark } \\
\text { purple with haemorrhage. Spleens were normal. }\end{array}$ & $\begin{array}{l}\text { Primary lesions were up to } 1 \mathrm{~cm} \text { thick, rubbery and not } \\
\text { gelatinous. Draining lymph nodes were up to eight } \\
\text { times normal size but not haemorrhagic. Spleens } \\
\text { were slightly enlarged. }\end{array}$ \\
\hline 20 & $\begin{array}{l}\text { Primary lesions were rubbery with the gelatinous material replaced } \\
\text { by a white fibromatous mass. Draining lymph nodes were still } \\
\text { enlarged and purple with haemorrhage. Contralateral nodes } \\
\text { and spleens were normal. }\end{array}$ & $\begin{array}{l}\text { Thick black scabs on lesions, tissue forming the bulk of } \\
\text { the lesion was solid and pale brown. Draining lymph } \\
\text { nodes were enlarged, up to three times normal, and } \\
\text { spleens were slightly enlarged. }\end{array}$ \\
\hline
\end{tabular}

subsequent degeneration and necrosis of these cells, loss of collagen structure, deposition of fibrin, infiltration of neutrophils and macrophages and proliferation of fibroblasts in the dermis. A particular feature was the presence in the dermis of the large stellate "myxoma cells" described by these authors and the disruption of the walls of the small blood vessels by similar cells which appeared to be migrating or budding from the blood vessel walls. The major histopathological features of the skin at the inoculation site were similar for both $S$. nuttallii and $S$. audubonii infected with $\mathrm{Lu}$, however there tended to be a stronger inflammatory response in the $S$. audubonii with many more polymorphs in the dermis and by day 20 the lesions were heavily scabbed compared to $S$. nuttallii. Lu antigen was present in the proliferating epidermal cells, particularly of the hair follicles and in elongated dermal cells of S. nuttallii and S. audubonii at day 5 (Fig. 7A-C). This pattern of virus localization to the epidermis with some infected cells in the dermis continued throughout the 20 days of the experiment (Fig. 7D). By day 20 the S. audubonii lesion was covered by a thick scab but the underlying cells were still packed with virus antigen (Fig. 7E).

$\mathrm{T}$ lymphocytes detected by CD43 staining were not a feature of the inflammatory response in the skin at days 5 and 10 for either species. T cells were largely restricted to the blood vessels with occasional cells in the lower dermis. $S$. audubonii had patches of $\mathrm{T}$ cells in the primary inoculation site at day 15 whereas these cells were not detected in S. nuttallii rabbits until day 20 (data not shown).

The histology of the lymphoid tissue draining or distal to the inoculation site was quite different to that seen in $O$. cuniculus infected with virulent strains of myxoma virus, where the key features are a reduction in lymphocyte numbers, often complete loss of lymphocytes, from the lymph nodes or spleen white pulp, degeneration of the follicles and a proliferation in size and number of reticulum cells. This is accompanied by focal or diffuse neutrophil infiltration into the nodes and vascular changes similar to those described in the skin (Best et al., 2000; Hurst, 1937a).
In contrast to this, the lymph nodes draining the inoculation site of both S. nuttallii and S. audubonii infected with Lu showed a similar range of histopathology predominantly associated with enlargement and activation of the node. There was no dramatic loss of lymphocytes although there was often considerable neutrophil infiltration and patches of necrosis and inflammation.

In S. nuttallii, Lu was detected in a few macrophages in the lymph node draining the inoculation site by immunoperoxidase staining at day 5 (Fig. 7F). Similar localisation in a few cells was present in the lymph node draining the inoculation site of $S$. audubonii infected with Lu (data not shown).

The contralateral popliteal lymph nodes were not as intensely affected as the popliteal lymph nodes draining the inoculation sites, however, the histological changes were generally similar but with far less swelling and fewer inflammatory cells. Cells infected with virus were rarely detected in the contralateral lymph nodes. Similarly there was little or no pathology in the spleens of infected animals of either species although by day 15 and 20 the white pulp areas of the spleens had considerably expanded in $S$. nuttallii and there were prominent secondary follicles present. Virus-infected cells were not detected.

\subsection{Virus localization and histopathology of MSW infection}

Californian strains of myxoma virus cause similar histopathology to South American strains in O. cuniculus (Kessel et al., 1934; Patton and Holmes, 1977; Silvers et al., 2006). MSW induced somewhat similar features to Lu at the inoculation site in S. nuttallii although there was a much stronger inflammatory response and in particular a macrophage response deep in the dermis. However, in $S$. audubonii there was a very intense mononuclear cell inflammatory response that dominated the histology and although some of the features of epidermal cell proliferation and myxoma cells could be discerned the overall response was of acute inflammation and in particular mononuclear cell infiltration. 

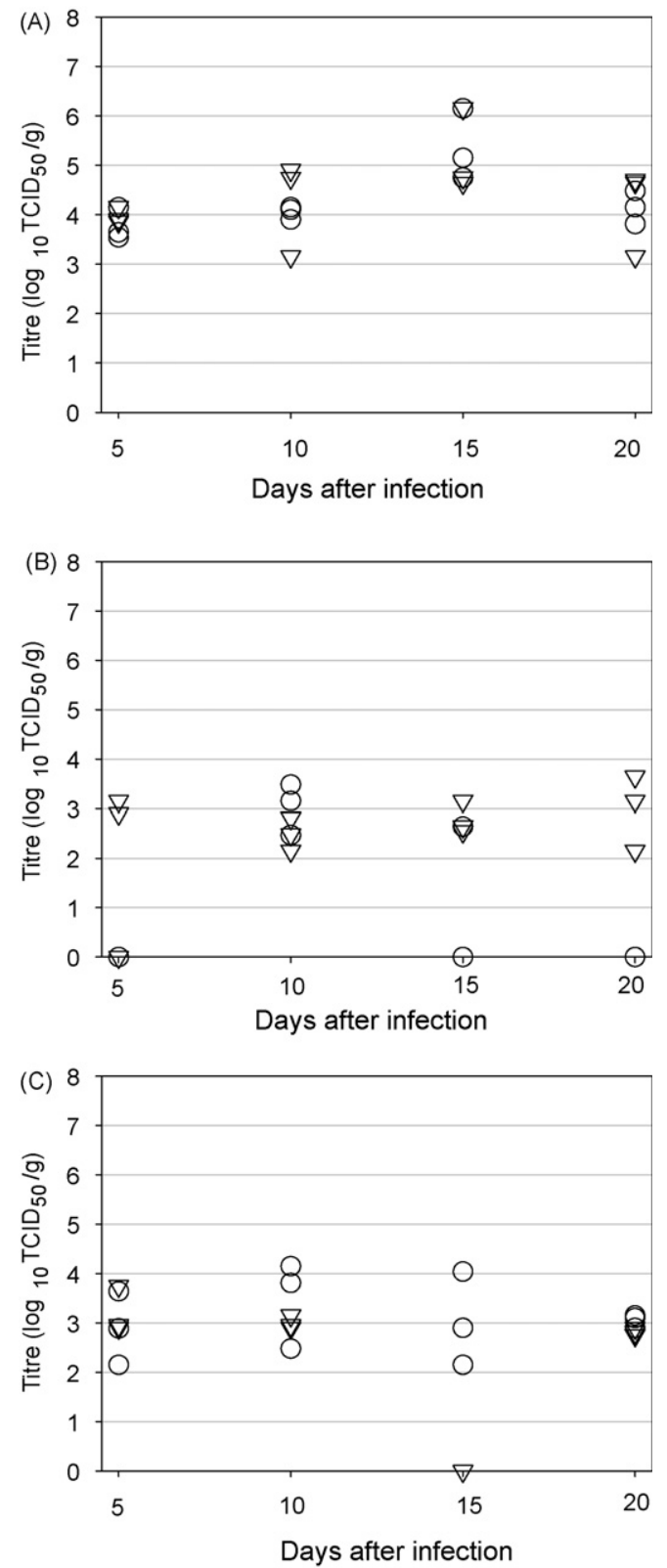

Fig. 6. Virus titres in $S$. nuttallii (circles) and $S$. audubonii (inverted triangles) infected with MSW: (A) skin at inoculation site; (B) draining lymph node; (C) distal skin. Limits of detection $100 \mathrm{TCID}_{50} / \mathrm{g}$.

At day 5 in $S$. nuttallii, MSW was localised to elongate cells in the dermis with only limited patches of infected cells in the epidermis (Fig. 7G). By day 10 patches of infected epidermal cells were more common but there were still many infected elongate cells in the dermis (Fig. 7H). This pattern continued through to day 20. S. audubonii infected with MSW had few infected cells in the skin of the inoculation site at day 5 (Fig. 7I) and even at day 10 only a few cells of hair follicles were positive along with the occasional elongate or macrophage-like cell in the dermis and, by day 20, occasional epidermal cells underlying the scab (Fig. 7J).
Staining for CD43 showed only the occasional T lymphocyte within blood vessels at day 5 in $S$. nuttallii (Fig. 7K). In contrast, at day 5 after infection with MSW, S. audubonii had an inflammatory response in the upper dermis with nuclear debris and mononuclear cells at the epidermal junction and polymorphs lower in the dermis. Staining of sections for CD43 showed a massive influx of T lymphocytes (Fig. 7L). The intense influx of T cells was also present in S. nuttallii at 10 days after inoculation and this continued to be a feature at 15 and 20 days (data not shown).

The draining lymph nodes of $S$. nuttallii infected with MSW had considerable extravasation of red blood cells in the paracortex together with macrophages containing brown pigment at day 5 . There were occasional patches of neutrophils. S. audubonii nodes had a range of histology at this time with one node showing patches of cells with an apoptotic appearance while others appeared similar to the S. nuttallii nodes. In both cases, the nodes largely returned to normal without showing significant pathology. MSW infected cells were not detected in draining lymph nodes of S. nuttallii or in contralateral lymph nodes. Occasional infected cells were detected in S. audubonii at day 5 at the periphery of the draining lymph node (data not shown).

Contralateral lymph nodes appeared normal in both species following MSW infection. In the spleens of both species, lymphocytes were congregated in the periarteriolar sheath regions at day 5 with scattered polymorphs in the red pulp. Follicle formation appeared to be more prevalent in S. audubonii than S. nuttallii. However, in both species, the appearance was of a normal response not a destructive pathology.

\section{Discussion}

The pathogenesis of either type of myxoma virus or rabbit fibroma virus has not been studied in detail in their natural hosts. Almost all studies have been done in European rabbits and all of the molecular studies of gene function reflect the pathogenesis in European rabbits. It appears that in their native hosts the viruses replicate in epidermal and dermal cells at the site of inoculation. Each virus encodes multiple proteins that locally suppress inflammation and innate and adaptive immune responses effectively ensuring that virus is able to persist long enough to be transmitted (Stanford et al., 2007). Cellular proliferation is induced by the secreted epidermal growth factor homologue leading to a virus-rich fibroma. In immunocompetent animals, immune responses eventually clear the virus, although, in the case of rabbit fibroma virus, lesions can persist for many months (Fenner and Ratcliffe, 1965; Yuill and Hanson, 1964). Secondary lesions are uncommon. Whether this is because the virus does not disseminate or is unable to establish and replicate to high titres at distal sites is not clear. However, more generalized disease has been reported in very young or newborns (Yuill and Hanson, 1964; Aragao, 1943; Fenner and Ratcliffe, 1965). This benign outcome of infection in immunocompetent hosts is seen as the result of prolonged host-virus coevolution (Fenner and Ratcliffe, 1965). 



Fig. 7. Immunoperoxidase staining of S. nuttallii and S. audubonii tissues following infection with Lu or MSW. (A) S. nuttallii infected with Lu: skin at inoculation site at day 5; brown staining indicates virus-infected cells $(100 \times)$. (B) S. audubonii infected with Lu: skin at inoculation site at day 5; brown staining indicates virus-infected cells $(100 \times)$. (C) S. nuttallii infected with Lu: dermis at inoculation site at day 5; brown staining indicates virus-infected cells $(400 \times)$. (D) S. nuttallii infected with Lu: skin at inoculation site at day 20; brown staining indicates virus-infected cells (100 $\times$ ). (E) S. audubonii infected with Lu: skin at inoculation site at day 20; brown staining indicates virus-infected cells $(100 \times ; S=$ scab). (F) S. nuttallii infected with Lu: draining lymph node at day 5; brown staining indicates virus-infected cells. Arrow indicates infected macrophage $(400 \times)$. (G) S. nuttallii infected with MSW: skin at inoculation site at day 5; brown staining indicates virus-infected cells $(100 \times)$. (H) S. nuttallii infected with MSW: skin at inoculation site at day 10 ; brown staining indicates virus-infected cells $(100 \times)$. (I) S. audubonii infected with MSW: skin at inoculation site at day 5; brown staining indicates virus-infected cells; examples indicated by arrows $(200 \times)$. (J) S. audubonii infected with MSW: skin at inoculation site at day 20; brown staining indicates virus-infected cells $(100 \times ; S=s c a b)$. (K) S. nuttallii infected with MSW: skin at inoculation site at day 5; T lymphocytes are stained brown (100 ×). (L) S. audubonii infected with MSW: skin at inoculation site at day 5; T lymphocytes are stained brown $(100 \times)$.

In European rabbits, myxoma virus disseminates from the primary site and replicates to high titres in distal tissues. There are two features that are important in the development of generalized lethal disease. Firstly, the replication of myxoma virus in $\mathrm{T}$ lymphocytes and macrophages and secondly the immune suppression of $\mathrm{T}$ lymphocyte responses (Strayer, 1992; Jeklova et al., 2008) and widespread destruction of lymphoid tissue (Hurst, 1937a; Best et al., 2000). At least five myxoma virus genes are essential for replication in $\mathrm{T}$ lymphocytes and macrophages (M002, M004, M005, M011, M013) (Stanford et al., 2007). In contrast, rabbit fibroma virus is unable to 
replicate in $\mathrm{T}$ cells from European rabbits and does not cause generalized disease in immunocompetent European rabbits (Fenner and Ratcliffe, 1965; Macen et al., 1996; Strayer et al., 1985). However, rabbit fibroma virus does reach distal tissues in European rabbits, at least following intratesticular injection (Hurst, 1937b; Fenner and Ratcliffe, 1965) and myxoma virus with the M011L gene deleted still caused large secondary cutaneous lesions indicating that it was able to disseminate (Opgenorth et al., 1992). So while replication in lymphocytes and macrophages is essential for a generalized disseminated infection, it seems that virus can still reach distal tissues. This suggests that the destruction of lymphoid tissue and associated immunosuppression is critical for virus replication to high titres at distal sites and development of generalized myxomatosis. No data are available on whether myxoma viruses can replicate in $\mathrm{T}$ lymphocytes in their native hosts but the localized pathogenesis would suggest that this is unlikely and that the genes that are essential for replication in T cells in European rabbits have been coopted from their function in virus infection of the native hosts.

Both $\mathrm{Lu}$ and MSW were able to replicate in S. nuttallii and $S$. audubonii but the outcome of infection differed between both virus type and lagomorph species. Neither virus caused the classical picture of myxomatosis seen in European rabbits. Lu induced a sustained infection at the inoculation site in both species together with some generalized clinical signs such as slightly swollen eyelids, red eyelid margins and swelling of the ano-genital region. These were more pronounced in $S$. nuttallii (it is possible that this represents a systemic response to infection rather than necessarily indicating virus replication). Marlier et al. (2000) demonstrated that European rabbits allowed to recover from myxomatosis and then stressed by administration of ACTH developed swollen eyelids, blepharoconjunctivitis and, in one case, genital swelling without virus being detected in these tissues although virus was detected in the testes. S. audubonii had a more rapid onset of clinical signs but were better able to mount an inflammatory response that led to scabbing of the primary lesion by day 20 despite quite high titres of virus still being present. Secondary lesion development at distal skin sites was uncommon in S. audubonii. These differences may reflect a generally more robust antiviral response in $S$. audubonii compared to $S$. nuttallii, which was also observed in the infections with MSW (see below), or may be due to more subtle differences in interactions of virus immunosuppressive and host-range proteins with host targets.

Although there were relatively high titres of $\mathrm{Lu}$ in the draining lymph nodes of $S$. nuttallii at day 5 , replicating virus was only detected in a few cells and not in the lymphocytes. At subsequent time-points Lu was not detectable in $S$. nuttallii draining lymph nodes. Lu was present at low titres in $S$. audubonii draining lymph nodes over most of the course of the infection. MSW was only present at low titres in the draining lymph nodes. Based on the immunohistology and the low titres of virus in lymphoid tissue, it appears that the viruses either did not replicate in lymphocytes or replicated below the levels of detection. Neither virus caused destruction of lymphoid tissue. Infected lymphocytes were readily detected by immunohistology in European rabbits infected with MSW and this was associated with destruction of lymphoid tissue (Silvers et al., 2006). Infectivity studies in primary lymphocytes would be required to definitively determine lymphotropism.

Virus could reach the draining node directly from the primary lesion. However, both viruses were detected at low titres in a number of distal tissues indicating that further dissemination from the primary lesion occurred despite the apparent lack of replication in lymphocytes. In distal tissues, there was limited spread from cell to cell and neither virus reached high titres (see for example Fig. 7F) except for the limited numbers of secondary skin lesions due to Lu. There are two possible explanations for this limited replication at distal sites despite the ongoing primary lesion acting as a source of virus. Firstly, virus replication at secondary sites may be limited by cell tropism for example in lymphocytes. However, this is not a sufficient explanation for lack of replication in secondary skin sites or eyelids since the virus can replicate in epidermis and some secondary lesions do occur particularly in S. nuttallii infected with Lu. A more general explanation is the high numbers of virus-infected cells in the primary lesion may be sufficient to suppress immune and inflammatory factors locally while a generalized upregulation of innate immune responses may be able to suppress virus replication at more distal sites. Antibody is unlikely to play a major role as titres were still low at day 10 , however, it is likely that virus-specific T cells were important in controlling virus replication at distal sites. In support of this idea, European rabbits inoculated with rabbit fibroma virus became partially protected from challenge with myxoma virus within 3-4 days (Hurst, 1937b). This supports the hypothesis that dissemination of myxoma virus is not sufficient to cause generalized myxomatosis in the absence of $\mathrm{T}$ cell suppression and lymphoid tissue destruction.

Based on the viral titres of Lu at the inoculation site, both species would have been able to transmit the virus via mosquitoes, as has been previously demonstrated by feeding mosquitoes on lesions (Regnery, 1971). S. nuttallii had transmissible titres of virus in primary and secondary lesions as late as day 20 while in S. audubonii titres were generally below the transmission threshold at days 15 and 20.

In contrast to infection with Lu, MSW did not replicate to high titres in either species and did not reach the threshold titres in the skin needed for efficient transmission by mosquitoes. This confirms previous transmission studies (Regnery and Marshall, 1971). While both species constrained MSW replication at the inoculation site, the inflammatory response was particularly dramatic in $S$. audubonii where infection with MSW induced a high fever with massive $\mathrm{T}$ lymphocyte influx into the site of infection by day 5 . This provided a potential explanation for why MSW appears limited to S. bachmani in nature even though S. audubonii overlaps with $S$. bachmani through much of its natural range and could be regularly exposed to myxoma virus by mosquitoes. However, despite this inflammatory response, MSW was able to persist and could be detected in 
all rabbits at the inoculation site throughout the experiment.

Preliminary sequence studies of the MSW genome have indicated a strong conservation of genes and nucleotide and amino acid sequences between Lu and MSW (Labudovic et al., 2004). The fact that Lu is able to replicate to high titres in both $S$. nuttallii and $S$. audubonii but that MSW is rapidly controlled, particularly in S. audubonii indicates that there must be differences in virulence or host-range genes between Lu and MSW that are important in $S$. audubonii and S. nuttallii but not in European rabbits.

The close genetic relationship between the three lagomorph-specific leporipoxviruses indicates that these have evolved from a common ancestral virus that has then diverged in the three species of lagomorph. These pathogenesis studies provide some clues to how this might have occurred. South American strains of myxoma virus have the potential to become established in both $S$. nuttallii and $S$. audubonii populations. This could occur without any previous adaptation of the virus as occurred with the introduction of myxoma virus into European rabbit populations in Australia. Subsequent adaption and speciation could occur in the new host. MSW, on the other hand, can infect other lagomorph species but does not replicate to transmissible titres in the skin. Thus some form of adaptive mutation would be required for MSW to jump species and successfully transmit.

Research has been conducted to develop recombinant myxoma viruses as vectors to deliver immunocontraceptive antigens to European rabbits in Australia (TyndaleBiscoe, 1994). While technological, epidemiological and social hurdles make it unlikely that such a strategy will be successful in the short to medium term (van Leeuwen and Kerr, 2007; Angulo and Cooke, 2002), it is possible that Californian strains of myxoma virus would offer greater species-specificity than South American strains of myxoma virus for engineering as recombinant myxoma virus vectors.

\section{Acknowledgements}

We thank Dr. A.J. Robinson and Dr. Tanja Strive for critically reading the manuscript. This work was funded by the Pest Animal Control Cooperative Research Centre.

\section{References}

Angulo, E., Cooke, B., 2002. First synthesize new viruses then regulate their release? The case of the wild rabbit. Mol. Ecol. 11, 2703-2709.

Aragao, H.D.B., 1943. O virus do mixoma no coelho do mato (Sylvilagus minensus) sua transmissao pelos Aedes scapularis e aegypti. Mem. Institut. Oswaldo Cruz 38, 93-99.

Best, S.M., Collins, S.V., Kerr, P.J., 2000. Coevolution of host and virus: cellular localization of myxoma virus infection of resistant and susceptible European rabbits. Virology 277, 76-91.

Best, S.M., Kerr, P.J., 2000. Coevolution of host and virus: the pathogenesis of virulent and attenuated strains of myxoma virus in resistant and susceptible European rabbits. Virology 267, 36-48.

Cameron, C., Hota-Mitchell, S., Chen, L., Barrett, J., Cao, J.-X., Macaulay, C., Willer, D., Evans, D., McFadden, G., 1999. The complete DNA sequence of myxoma virus. Virology 264, 298-318.

Fenner, F., 1965. Viruses of the myxoma-fibroma subgroup of the poxviruses. II. Comparison of soluble antigens by gel diffusion tests, and a general discussion of the subgroup. Aust. J. Exp. Biol. Med. Sci. 43, 143-156.
Fenner, F., Day, M.F., Woodroofe, G.M., 1956. Epidemiological consequences of the mechanical transmission of myxomatosis by mosquitoes. J. Hyg. (Camb.) 54, 284-303.

Fenner, F., Fantini, B., 1999. Biological Control of Vertebrate Pests. The History of Myxomatosis-An Experiment in Evolution. CAB International, New York.

Fenner, F., Marshall, I.D., 1957. A comparison of the virulence for European rabbits (Oryctolagus cuniculus) of strains of myxoma virus recovered in the field in Australia, Europe and America. J. Hyg. (Camb.) 55, 149-151.

Fenner, F., Ratcliffe, F.N., 1965. Myxomatosis. Cambridge University Press, Cambridge, England.

Fountain, S., Holland, M.K., Hinds, L.A., Janssens, P.A., Kerr, P.J., 1997. Interstitial orchitis with impaired steroidogenesis and spermatogenesis in the testes of rabbits infected with an attenuated strain of myxoma virus. J. Reprod. Fertil. 110, 161-169.

Fox, R.R., 1994. Taxonomy and genetics. In: The Biology of the Laboratory Rabbit, Academic Press, pp. 1-26.

Hurst, E.W., 1937a. Myxoma and the Shope fibroma. I. The histology of myxoma. Br. J. Exp. Pathol. 18, 1-15.

Hurst, E.W., 1937b. Myxoma and the Shope fibroma. III. Miscellaneous observations bearing on the relationship between myxoma, neuromyxoma and fibroma viruses. Br. J. Exp. Pathol. 18, 23-30.

Jeklova, E., Leva, L., Matiosovic, J., Kovarcik, K., Kudlackova, H., Nevorankova, Z., Psikal, I., Faldyna, M., 2008. Characterisation of immunosuppression in rabbits after infection with myxoma virus. Vet. Microbiol. 129, 117-130.

Kerr, P.J., 1997. An ELISA for epidemiological studies of myxomatosis: persistence of antibodies to myxoma virus in European rabbits (Oryctolagus cuniculus). Wildl. Res. 24, 53-65.

Kerr, P.J., McFadden, G., 2002. Immune responses to myxoma virus. Viral Immunol. 15, 229-246.

Kessel, J.F., Fisk, R.T., Prouty, C.C., 1934. Studies with the Californian strain of the virus of infectious myxomatosis. In: Fifth Pacific Science Congress. pp. 2927-2939.

Labudovic, A., Perkins, H., van Leeuwen, B., Kerr, P., 2004. Sequence mapping of the Californian MSW strain of myxoma virus. Arch. Virol. 149, 553-570.

Lebarbenchon, C., Brown, S.P., Poulin, R., Gauthier-Clerc, M., Thomas, F., 2008. Evolution of pathogens in a man-made world. Mol. Ecol. 17, 475-484.

Macen, J.L., Graham, K.A., Fong Lee, S., Schreiber, M., Boshkov, L.K., McFadden, G., 1996. Expression of the myxoma virus tumour necrosis factor receptor homologue and M11L genes is required to prevent virus-induced apoptosis in infected rabbit T lymphocytes. Virology 218, 232-237.

Marlier, D., Mainil, J., Sulon, J., Beckers, J.F., Linden, A., Vindevogel, H., 2000. Study of the virulence of five strains of amyxomatous myxoma virus in crossbred New Zealand White/Californian conventional rabbits, with evidence of long-term testicular infection in recovered animals. J. Comp. Pathol. 122, 101-113.

Marshall, I.D., Regnery, D.C., 1963. Studies in the epidemiology of myxomatosis in California. III. The response of brush rabbits (Sylvilagus bachmani) to infection with exotic and enzootic strains of myxoma virus and the relative infectivity of the tumours for mosquitoes. Am. J. Hyg. 77, 213-219.

Marshall, I.D., Regnery, D.C., Grodhaus, G., 1963. Studies in the epidemiology of myxomatosis in California. I. Observations on two outbreaks of myxomatosis in coastal California and the recovery of myxoma virus from a brush rabbit (Sylvilagus bachmani). Am. J. Hyg. 77, 195-204.

McFadden, G., 2005. Poxvirus tropism. Nat. Rev. Microbiol. 3, 201-213.

Opgenorth, A., Graham, K., Nation, N., Strayer, D., McFadden, G., 1992. Deletion analysis of two tandemly arranged virulence genes in myxoma virus, M11L and myxoma growth factor. J. Virol. 66, 4720-4731.

Patton, N.M., Holmes, H.T., 1977. Myxomatosis in domestic rabbits in Oregon. J. Am. Vet. Assoc. 171, 560-562.

Patz, J.A., Daszak, P., Tabor, G.M., Aguirre, A.A., Pearl, M., Epstein, J., Wolfe, N.D., Kilpatrick, A.M., Foufopoulos, J., Molyneux, D., Bradley, D.J., 2004. Unhealthy landscapes: policy recommendations on land use change and infectious disease emergence. Environ. Health Perspect. 112 , 1092-1098.

Regnery, D.C., 1971. The epidemic potential of Brazilian myxoma virus (Lausanne strain) for three species of North American cottontails. Am. J. Epidemiol. 94, 514-519.

Regnery, D.C., Marshall, I.D., 1971. Studies in the epidemiology of myxomatosis in California. IV. The susceptibility of six leporid species to Californian myxoma virus and the relative infectivity of their tumours for mosquitoes. Am. J. Epidemiol. 94, 508-513. 
Rivers, T.M., 1930. Infectious myxomatosis of rabbits: observations on the pathological changes induced by virus myxomatosis (Sanarelli). J. Exp. Med. 51, 965-975.

Silvers, L., Inglis, B., Labudovic, A., Janssens, P.A., van Leeuwen, B.H., Kerr, P.J., 2006. Virulence and pathogenesis of the MSW and MSD strains of Californian myxoma virus in European rabbits with genetic resistance to myxoma virus compared to rabbits with no genetic resistance. Virology 348, 72-83.

Stanford, M.M., Werden, S.J., McFadden, G., 2007. Myxoma virus in the European rabbit: interactions between the virus and its susceptible host. Vet. Res. 38, 299-318.

Strayer, D.S., 1992. Determinants of virus-related suppression of immune responses as observed during infection with an oncogenic poxvirus. In: Melnick, J.L. (Ed.), Progress in Medical Virology. Karger, Basel, pp. 228-255.

Strayer, D.S., Skaletsky, E., Leibowitz, J.L., 1985. In vitro growth of two related leporipoxviruses in lymphoid cells. Virology 145, 330-334.
Tyndale-Biscoe, C.H., 1994. Virus-vectored immunocontraception of feral mammals. Reprod. Fertil. Dev. 6, 9-16.

van Leeuwen, B.H., Kerr, P.J., 2007. Prospects for fertility control in the European rabbit (Oryctolagus cuniculus) using myxoma virus-vectored immunocontraception. Wildl. Res. 34, 511-522.

Wilkinson, J.M., Galea-Lauri, J., Sellars, R.A., Boniface, S.C., 1992. Identification and tissue distribution of rabbit leucocyte antigens recognized by monoclonal antibodies. Immunology 76, 630-635.

Willer, D.O., McFadden, G., Evans, D.H., 1999. The complete genome sequence of Shope (rabbit) fibroma virus. Virology 264, 319343.

Woodroofe, G.W., Fenner, F., 1965. Viruses of the myxoma-fibroma subgroup of the poxviruses. I. Plaque production in cultured cells, plaquereduction tests and cross-protection tests in rabbits. Aust. J. Exp. Biol. Med. Sci. 43, 123-142.

Yuill, T.M., Hanson, R.P., 1964. Infection of suckling cottontail rabbits with Shope's fibroma virus. Proc. Soc. Exp. Biol. Med. 117, 376-380. 